\title{
SISTEM PAKAR PENCEGAHAN EPIDEMI DEMAM BERDARAH DENGUE
}

\author{
Ria Arafiyah ${ }^{1}$, Med Rizal $^{1}$, Agus Buono ${ }^{2}$, I Made Dewa Subrata ${ }^{3}$ \\ ${ }^{1}$ Computer System Study Program, Department of Math \\ Faculty of Natural Science and Mathematics UNJ \\ Jl. Rawamangun Muka Jakarta Timur ,Jakarta, Indonesia \\ ${ }^{2}$ Department of Computer Science \\ Faculty of Natural Science and Mathematics, IPB \\ Bogor,Jawa Barat, Indonesia \\ ${ }^{3}$ Department of Mechanical Engineering Biosystem \\ Faculty of Engineering Technology Agriculture, IPB \\ Bogor,Jawa Barat, Indonesia \\ ria_lamrat@yahoo.com
}

\begin{abstract}
ABSTRAK
Salah satu masalah pencegahan dan pemberantasan penyakit menular yang sampai saat ini masih merupakan masalah kesehatan masyarakat adalah penyakit Dengue Haemorhagic Fever atau yang lebih dikenal dengan nama Demam Berdarah Dengue (DBD). Sejak tahun 1968, di Indonesia penyebaran penyakit DBD semakin meluas keseluruh wilayah Indonesia dan beberapa wilayah yang setiap tahunnya selalu ditemukan kasus sebagai daerah endemis. Penelitian ini bertujuan mengembangkan sistem pakar pencegahan epidemi demam berdarah dengue yang akan memberikan rekomendasi bagi pemerintah untuk melakukan langkah-langkah pencegahan yang optimal di daerah tersebut. Dengan adanya sistem pakar pencegahan epidemi DBD ini, diharapkan pemerintah daerah dapat lebih cepat dan efisien dalam membuat kebijakan karena dapat menggantikan para pakar dalam memberikan saran pencegahan.

Input Sistem adalah karakteristik daerah (kepadatan penduduk, akses transportasi umum), kesehatan lingkungan (keganasan virus dan angka bebas jentik), sedangkan output sistem adalah saran penanganan terhadap vektor DBD (nyamuk dan jentik), intensitas penyuluhan kesehatan lingkungan. Berdasarkan wawancara pakar dan penelusuran referensi dibangun rule base yang mendasari sistem pakar untuk membuat kesimpulan.
\end{abstract}

Kata Kunci: Sistem Pakar, epidemi DBD

\section{PENDAHULUAN}

Salah satu masalah pencegahan dan pemberantasan penyakit menular yang sampai saat ini masih merupakan masalah kesehatan masyarakat adalah penyakit Dengue Haemorhagic Fever atau yang lebih dikenal dengan nama Demam Berdarah Dengue (DBD). Vektor penyakit DBD ini adalah nyamuk Aedes aegypti melalui gigitan yang berulang-ulang kepada orang yang susceptible (rentan). Malaysia dan Singapura telah berhasil mencanangkan bebas demam berdarah karena adanya perhatian Pemerintah terhadap masalah Kesehatan Lingkungan, dengan melegitimasi persoalan kesehatan lingkungan dalam bentuk peraturan dan sangsi bagi rumah yang terdapat jentik nyamuk. Sementara Indonesia sejak 
tahun 1968 penyebaran penyakit DBD semakin meluas keseluruh wilayah Indonesia bahkan beberapa wilayah setiap tahunnya selalu menjadi daerah epidemi..

Upaya pencegahan penyebaran penyakit DBD melalui pemberantasan sarang nyamuk (PSN) dan pengendalian kasus belum berjalan secara optimal, karena didalam pemberantasan penyakit DBD tidak hanya memberantas nyamuk Aedes aegypti saja, tetapi juga memberantas virus dengue yang dibawa oleh nyamuk tersebut. Dengan demikian penekanan pemberantasan juga diarahkan pada upaya pengurangan jumlah nyamuk yang dapat membawa virus dengue dengan cara membunuh jentiknya. Sementara itu untuk menghilangkan jentik (larva) kurang mendapat perhatian dari masyarakat karena dianggap merupakan upaya yang tidak jelas hasilnya dibandingkan dengan pengasapan. (Sumantri A, 2008)

Demam berdarah dengue (DBD) masih merupakan masalah kesehatan masyarakat dan menimbulkan dampak sosial maupun ekonomi. Hasil survei menunjuk bahwa pengetahuan masyarakat tentang BDB masih kurang (Soeparmanto Paiman, dkk, 2000)..

Penelitian ini bertujuan mengembangkan sistem pakar pencegahan epidemi demam berdarah dengue yang akan memberikan rekomendasi bagi pemerintah untuk melakukan langkah-langkah pencegahan yang optimal. Pengetahuan sistem pakar dibangun dari informasi yang didapat dari para pakar kesehatan lingkungan, petugas kesehatan, dan penelusuran referensi sehingga didapat rule yang mendasari sistem pakar dalam membuat kuputusan.

\section{TINJAUAN PUSTAKA \\ Sejarah Epidemi Dengue}

Penyakit Dengue merupakan salah satu penyakit menular yang berbahaya dapat menimbulkan kematian dalam waktu singkat dan sering menimbulkan wabah (Siregar, 2004). Penyakit tersebut pertama kali ditemukan pada tahun 1801 di Spanyol, tetapi istilah dengue pertama kali menjadi popular sejak terjadinya epidemik di Kuba tahun 1828. Kata dengue yang dalam bahasa Spanyol berarti sopan santun karena sikap membungkuk, mencerminkan cara berjalan penderita akibat rasa nyeri pada tulang dan sendi serta gangguan motorik pada lutut dan mata kaki.

Virus dengue termasuk virus RNA, kelompok Arthropod Borne Virus (Arbovirus), genus Flavivirus familia Falviviridae, bentuk batang, berukuran $50 \mathrm{~mm}$, bersifat termolabil, stabil pada suhu penyimpanan $-70^{\circ} \mathrm{C}$. Virus ini diisolasi pada tahun 1944 oleh Sabin dan kawan-kawan dari US Army di India, Papua New Guenea, dan Hawaii (Sabin 1952 dalam Gubler et al, 1979). Kelompok ini juga mengembangkan uji haemaglutination inhibition test (Hi test) untuk uji serologis. Virus yang ditemukan dari Hawaii disebut dengue - 1 (DEN-1) dan dari Papua New Guenea disebutnya DEN-2 dan hasil dari isolasi dari pasien DBD pada epidemik di Manila tahun 1956 disebut DEN-3 dan DEN-4 (Gubler, 1979). Untuk membedakan jenis virus, Poorwosoedarmo (1988) menggunakan istilah tipe dengue 1, 2, 3, dan 4. Keempat serotipe virus dengue tersebut ditemukan di berbagai daerah, tetapi yang dominan di Indonesia adalah serotipe DEN 3.

Pada awalnya virus dengue hanya terdapat didalam hutan Afrika, jauh dari kehidupan manusia. Virus ini ditransmisikan ke manusia oleh Aedes aeagypti dan Aedes albopictus (Gubler et al, 1979) yang telah beradaptasi dengan lingkungan peridomestik dan bertelur di genangan-genangan air di sekitar lingkungan pemukiman akibat pembakaran hutan. Virus dengue tersebar keluar Afrika melalui perdagangan budak pada abad ke 17-19. Wabah DD/DBD mulai masuk ke Asia sesudah Perang Dunia II.

Di Asia Tenggara pertama kali terjadi di Manila Filipina pada tahun 1953 - 1954 dan kemudian tahun 1956 terulang kembali. Wabah demam yang terjadi di Filipina pada tahun 
1953 menyerang anak-anak disertai manifestasi perdarahan dan renjatan, dengan angka kematian hingga $6 \%$ (Gubler et al, 1979). Untuk membedakan dengan wabah DBD yang sedang diteliti di Korea saat itu, maka wabah tersebut diberi nama Philippine Haemorhagic Fever. Epidemi di Bangkok, tahun 1958 mencapai angka kematian $10 \%$. Saat itu di Hanoi, Vietnam Utara juga mengalami kejadian sama. Wabah juga terjadi di Singapura pada tahun 1960, Malaysia antara tahun 1962-1964 dan di Calcutta, India pada tahun 1963. (Poorwosoedarmo, 1988). Penyakit demam berdarah dengue (DBD) pertama kali ditemukan di Kota Manila (Philipina) pada tahun 1953 kemudian menyebar ke berbagai negara. Penyakit ini sering menimbulkan wabah dan menyebabkan kematian pada banyak orang terutama anak-anak. Berikutnya wabah muncul berulang setiap tiga hingga lima tahun di banyak negara Asia Tenggara.

Di Indonesia penyakit ini ditemukan pada tahun 1968 di Surabaya tetapi konfirmasi virologist baru diperoleh pada tahun 1970 dan DKI Jakarta pertama kali dilaporkan (Kho, 1969 dalam Poorwosoedarmo, 1988) dan mulai menjadi wabah pada tahun 1973 kemudian menyebar ke berbagai wilayah. Kini semua propinsi yang ada di Indonesia sudah terjangkit penyakit DBD di berbagai kota maupun desa terutama yang padat penduduknya dan arus transportasinya lancar.

Indonesia menempati urutan kedua setelah Thailand, menurut Suroso (2001) menyebutkan, bahwa sejak ditemukannya kasus DBD di Surabaya tahun 1968 terus terjadi peningkatan dari 0,05 pada tahun 1968 menjadi 35,19 pada tahun 1998 per 100.000 penduduk. Sejak 1994 seluruh propinsi di Indonesia telah melaporkan kasus DBD (Departemen Kesehatan, 2003), Case Fatality Rate (CFR) tercatat 2,22 \% pada tahun 1997. KLB tahun 2004 yang terjadi pada bulan Januari sampai April dengan jumlah kasus di seluruh Indonesia 58.861 dan 669 meninggal, di DKI Jakarta tercatat 16.950 kasus dengan 79 meninggal atau incidence rate (IR) sebesar 150,7 per 100.000 penduduk dan CFR 0,4. CFR untuk seluruh Indonesia adalah 2,0 tetapi di beberapa daerah seperti Nusa Tenggara Timur mencapai 4,0, Yogyakarta sebesar 3,8 dan Sulawesi Selatan 3,6.

\section{Kasus DBD di Wilayah DKI Jakarta}

Wilayah DKI Jakarta sejak tahun 2001 sampai dengan 2006, kasus DBD merupakan kasus yang terus menerus terjadi, bahkan sudah bisa disebut sebagai suatu siklus tahunan yang terus berulang, bahkan pada tahun 2004 bulan februari dan maret, terjadi KLB DBD (7072 kasus) untuk wilayah DKI Jakarta secara umum. 


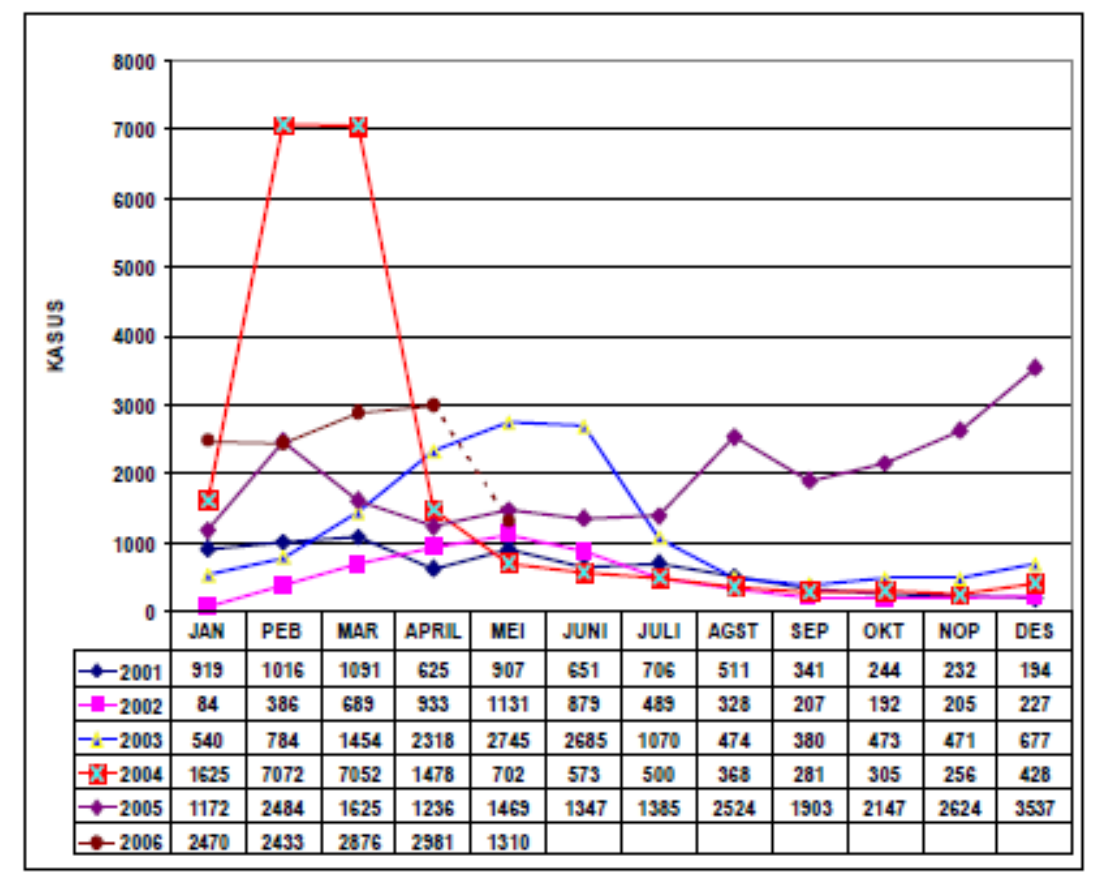

Gambar 2. Jumlah Kasus DBD Bersumber Surveilans Aktif RS Per Bulan di DKI Jakarta, 2001 - 2006 (s.d 17 Mei 2006)

Proses pengendalian nyamuk Aedes aegypti sebagai vektor pembawa penyakit DBD dilakukan dengan berbagai cara, antara lain : Fogging (penyemprotan di daerah yang posistif atau negative DBD), pemberian abate sebagai cara pengendalian jentik nyamuk, program $3 \mathrm{M}$ yang dilakukan secara berkesinambungan diseluruh wilayah DKI Jakarta.

Daerah (kelurahan) yang akan dikontrol dibedakan berdasarkan stratafikasi daerah (kelurahan) berdasarkan jumlah penderita DBD, dengan kriteria sebagai berikut:

Tabel 1. Klasifikasi Daerah Berdasarkan Kasus DBD di Suatu Kelurahan

\begin{tabular}{|c|l|}
\hline KATEGORI & \multicolumn{1}{c|}{ KETENTUAN } \\
\hline MERAH & Dalam 1 minggu terjadi lebih dari 5 kasus DBD \\
\hline KUNING & Dalam 1 minggu terjadi 1-5 kasus DBD \\
\hline HIJAU & Dalam 3 minggu terjadi lebih dari 1-5 kasus DBD \\
\hline PUTIH & Dalam 3 minggu berturut-turut tidak terjadi kasus DBD \\
\hline
\end{tabular}

\section{Sistem Pakar}

Sistem pakar (expert system) adalah sistem yang berusaha mengapdosi pengetahuan manusia ke komputer, agar komputer dapat menyelesaikan masalah seperti yang biasa dilakukan oleh para ahli. Sistem pakar yang baik dirancang agar dapat menyelesaikan suatu permasalahan tertentu dengan meniru kerja dari para ahli. Dengan sistem pakar, orang awam pun dapat menyelesaikan masalah yang cukup rumit yang sebenarnya hanya dapat diselesaikan dengan bantuan para ahli. Bagi para ahli, sistem pakar juga akan membantu aktivitasnya sebagai asisten yang sangat berpengalaman. Sistem pakar dikembangkan pertama kali tahun 1960. (Marimin,2001). Contoh sistem pakar yang terkenal adalah MYCIN untuk diagnose penyakit. Adapun arsitektur sistem pakar di bawah ini adalah sebagai berikut: 


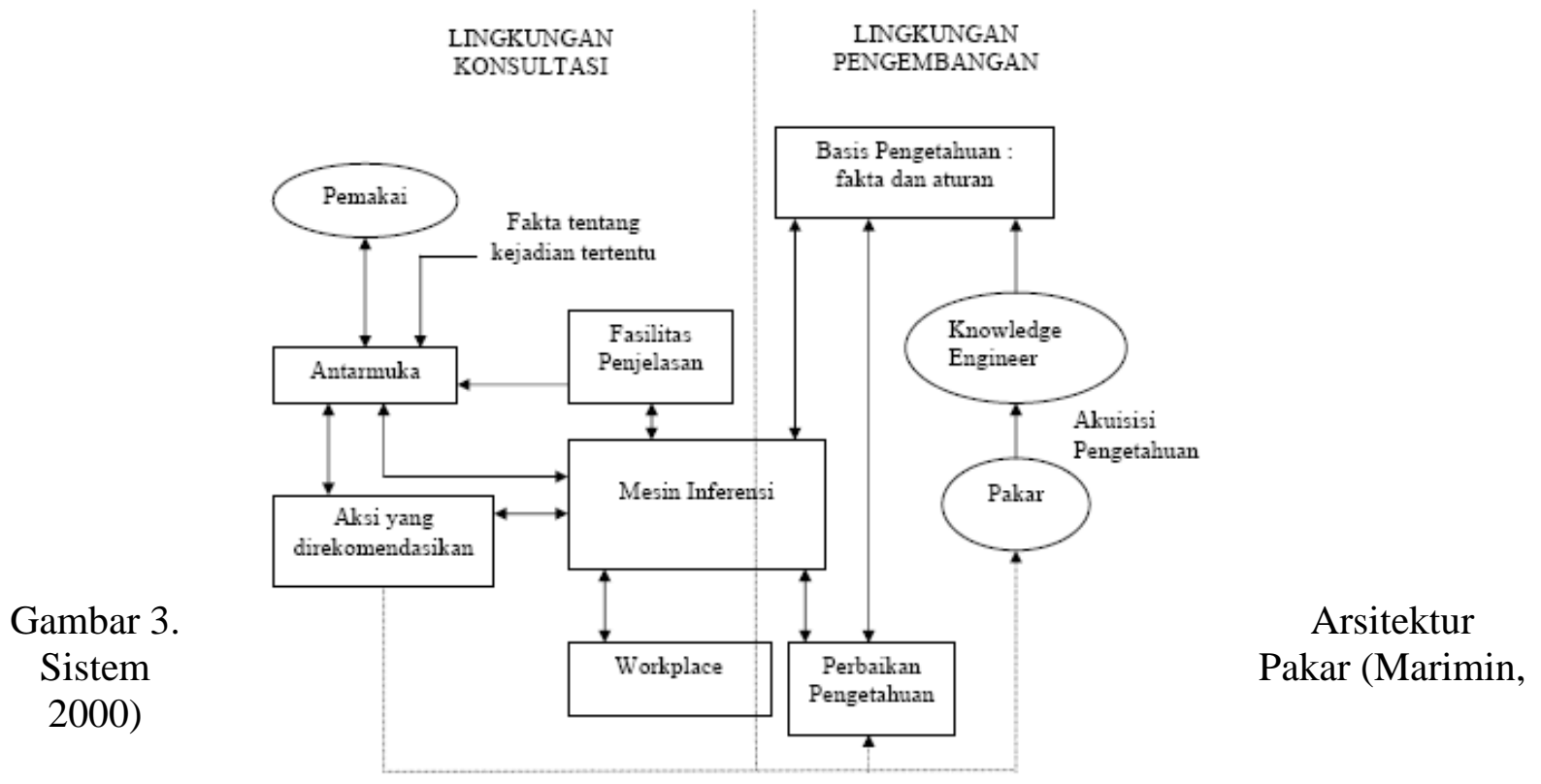

Pengetahuan adalah pemahaman teoritis atau praktis dari suatu subjek. Pada sistem pakar, pengetahuan seorang pakar dirumuskan dalam rule of thumb / ugeran dan direpresentasikan menggunakan silogisme logika seperti logika $I F$... THEN..., AND, OR, model matematika, pencarian derajat kemiripan $(R)$ dll. Dengan informasi berupa ugeran tersebut, sistem pakar dapat melakukan 2 macam inferensi (penelusuran), yaitu; pertama menarik kesimpulan berdasarkan fakta-fakta yang ada (inferensi maju), kedua, Mencoba membuktikan hipotesis dengan merunut fakta-fakta yang mendukung (inferensi mundur). Sistem pakar juga mampu menarik kesimpulan berupa perkiraan dengan kemungkinan terbesar walaupun terdapat ketidakjelasan, kekurangan, atau ketidaksesuaian input. Hal ini dilakukan menggunakan certainty factor pada logika $I F$... THEN ..., faktor signifikansi pada logika pencarian derjat kemiripan $R$, bobot neuron pada sistem jaringan saraf, dan lain-lain. Kumpulan informasi ugeran tentang suatu masalah khusus disebut dengan basis pengetahuan (knowledge base). Karena rumusan ugeran dalam bentuk silogisme logika, maka ugeran terdiri dari fakta (antecendent) dan kesimpulan (konsekuen).

Kumpulan fakta dan kesimpulan penunjang ugeran, contoh kasus, parameterparameter sistem pakar, spesifikasi nilai input, dan kalimat-kalimat untuk interaksi dengan pengguna disimpan dalam dalam basis data (database). Pengguna melakukan interaksi dengan sistem pakar dengan menjawab pertanyaan interaktif atau memasukkan input yang telah disediakan oleh basis data sistem pakar. Selanjutnya sistem pakar melakukan inferensi berdasarkan informasi dalam basis data dengan ugeran dalam basis pengetahuan untuk menghasilkan kesimpulan-kesimpulan atau buktibukti intermediet sampai memperoleh solusi/kesimpulan akhir atau pembuktian dari suatu hipotesa.

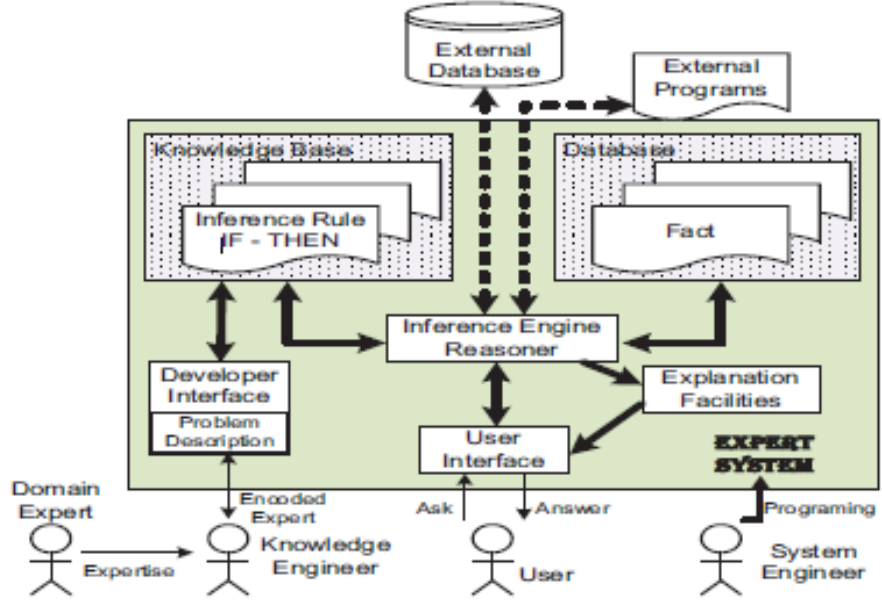




\section{Gambar 4. Skema Umum Kerja Sistem Pakar}

(Hart A, 1986)

Penelitian-penelitian yang sudah dilakukan dan yang akan digunakan dalam penelitian ini adalah: Badan Penelitian dan Pengembangan Kesehatan, Depkes RI, (2004), mengenai Kajian Kesehatan demam Berdarah Dengue. Hasilnya adalah cara yang paling efektif untuk mencegah penyakit DBD adalah Pemberantasan Sarang Nyamuk (PSN) dengan "3M Plus" yang melibatkan seluruh masyarakat serta disesuaikan dengan kondisi setempat. Paiman Soeparmanto (2000) mengenai Peningkatan Penanggulangan Demam Berdarah Dengue (DBD) Berbasis Masyarakat dengan Pendekatan Pendidikan Kesehatan. Hasilnya partisipasi masyarakat dapat ditingkatkan untuk membasmi sarang nyamuk Aedes Aegypti dengan penyuluhan yang digalakkan oleh Community Organizer dibantu pemuka-pemuka masyarakat, kader kesehatan dan ibu-ibu PKK. Irnawati Marsaulina S dan Arlinda Sari Wahyu (2006) Strategi Pencegahan Kejadian Luar Biasa (KLB) Demam Berdarah melalui pendekatan faktor risiko di kota Medan.

Arna Fariza, (2002), mengenai Performasi Neuro Fuzzy untuk Peramalan data Time Series. Hasilnya adalah metode ANFIS memiliki hasil yang sangat baik untuk peramalan data saham. Syafii, M. (2006) menggunakan ANFIS untuk memodelkan sistem diagnosa dan membuat sistem pakar tatalaksana penyakit demam berdarah dengue. Prof. The Houw Liong ITB, (2007) memprediksi banjir besar JABODETABEK menggunakan ANFIS. Banjir sesuai dengan data waktu puncak aktifitas matahari (1981, 2002) dan aktifitas minimum (1996, 2007). Input model yang mereka kembangkan berupa deret waktu suatu kuantitas (bilangan sunspot, curah hujan, tinggi muka air, dsb). Arafiah Ria dan Alimuddin (2010) mengenai Prediction of price of local fruits in Jakarta with ANFIS . Hasilnya adalah prediksi secara baik dan akurat dengan error relatif kecil. Pradana dan Kusuma S, (2007) mengenai Kajian Aplikasi Diagnosis Penyakit Hepatitis Untuk Mobile Devices Menggunakan J2ME. Hasilnya adalah diagnosis penyakit hepatitis meliputi panduan pengamatan, pendeteksian, dan diagnosa dengan menggunakan sistem J2ME berbasis kaidah dan kasus. Sumantri Arif, Model Pencegahan Berbasis Lingkungan Terhadap Penyakit Demam Berdarah Dengue Propinsi DKI Jakarta, Hasilnya mengetahui pencegahan penyakit demam berdarah dengue berbasis lingkungan secara baik dan akurasi. Puspitasari D 2009, Sistem Pakar Diagnosa Diabetes Nefropathy dengan metode Certainty Factor Berbasis Web dan Mobile, menghasilkan pengetahuan akurat berdasarkan pengetahuan pakar dan dapat membatu melakukan diagnosis penyakit. Sintorini, M.M. 2006, Dinamika Penularan Demam Berdarah Dengue (DBD) dalam Kaitan dengan Pola Variabilitas Iklim (Studi Kasus DBD di DKI Jakarta), menghasilkan kaitan antara penularan DBD dengan variabilitas Iklim.

\section{METODE PENELITIAN}

Penelitian ini dilaksankan mulai Mei 2015 sampai Desember 2015. Penelitian lapangan di lakukan di DKI Jakarta. Penelitian laboratorium dilaksanakan di Laboratorium Komputer Jurusan Matematika, Fakultas Matematika dan Ilmu Pengetahuan Alam Universitas Negeri Jakarta dan Jurusan Ilmu Komputer Institut Pertanian Bogor.

Bahan yang digunakan untuk membuat sistem pakar pencegahan epidemi DBD adalah basis data yang berasal dari data lapangan. Data yang berasal dari lapangan adalah karakteristik daerah (kepadatan penduduk, akses transportasi umum), kesehatan lingkungan (keganasan virus dan angka bebas jentik). Perancangan Sistem Pakar pencegahan epidemi DBD menggunakan software MATLAB R2012a..

\section{Pembuatan Sistem Pakar}

\section{Analisis}


Analisis dilakukan dengan menggali informasi mengenai faktor-faktor utama yang dibutuhkan yang mempengaruhi sistem pencegahan penyakit demam berdarah dengan variabel kepadatan penduduk, akses transpormasi umum, keganasan virus, dan angka bebas jentik. Setelah itu dilakukan analisis terhadap pendapat pakar dan kaitannya dengan variabel input.

2. Perancangan dan Pembuatan Sistem

Perancangan dan pembuatan sistem dilalui dengan beberapa tahapan didalamnya, yaitu merancang rule base sistem pakar, menggunakan variabel input untuk mendapatkan output yang sesuai sehingga lolos dalam tahap pengujian.

3. Pengujian

Dalam tahap ini dilakukan pengujian sistem dengan menggunakan data base yang telah dibangun.

4. Evaluasi

Pada tahap evaluasi ini, dilihat simpulan yang dapat ditarik dari hasil pengujian sistem. Jika ternyata hasil pengujian dirasakan tidak sesuai atau tidak menghasilkan nilai yang lebih baik, maka dilakukan kembali tahapan awal untuk memperoleh hasil yang lebih baik lagi.

Pada bagian ini akan dibahas prosedur perancangan, procedur perancangan terdiri dari tahapan :

1. Langkah pertama adalah mendesain basis pengetahuan. Dilakukan dengan cara membuat pohon keputusan (decision tree). Terdapat dua bagian dalam pohon keputusan, node keputusan dan node konklusi.

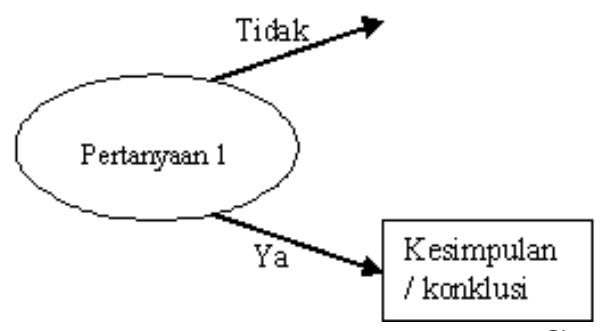

Gambar 5 : Pohon Keputusan

2. Selanjutnya melakukan konversi dari Pohon Keputusan kedalam himpunan aturan IFTHEN, contoh :

IF pertanyaan $1=\mathrm{Ya}$

THEN kesimpulan

3. Langkah terakhir adalah pengolahan basis pengetahuan. Untuk lebih jelasnya lihat pada bagian implementasi.

\subsection{Implementasi Sistem}

Bagian ini membahas mengenai implementasi komponen-komponen pembentuk sistem pakar yaitu : Basis pengetahuan, Mesin inferensi dan Antar muka pemakai

\section{Basis pengetahuan}

Basis pengetahuan merupakan representasi dari pengetahuan dari seorang pakar yang merupakan pola atau susunan dari fakta-fakta tentang objek dalam ruang lingkup suatu pengetahuan.

Implementasi basis pengatahuan berdasarkan perancangan sistem dilakukan dengan cara :

1. Pengisian tabel variabel : untuk menentukan pertanyaan

2. Pengisian table konklusi : untuk menentukan konklusi akhir 


\section{Pembuatan tabel himpunan aturan (IF-THEN rule)}

\section{Mesin Inferensi}

Mesin infersnsi pada dasarnya adalah memilih pengetahuan yang ralevan dalam rangka mencapai kesimpulan. Terdapat dua metode pelacakan untuk mesin infersnsi ini yaitu, Forward chaining dan Backward chaining. Pada penelitian ini metode yang digunakan adalah Forward chaining dimana pencocokan fakta atau pernyataan di mulai dari bagian sebelah kiri (bagian IF), dengan kata lain penalaran di mulai dari fakta terlebih dahulu untuk menguji kebenaran hipotesis.

Teknik Inferensi Forward chaining dapat diimplementasikan sebagai berikut :

1. Kondisi ditentukan terlebih dahulu.

2. Variabel kondisi disimpan di antrian variabel konklusi dan nilainya ditandai di daftar varibel.

3. Daftar variabel klausa dicari untuk variabel yang mempunyai nama yang sama seperti variable pertama di antrian variabel konklusi. Jika ditemukan, nomor aturan dan nomor variabel klausa disimpan ke dalam penunjuk variabel klausa. Jika tidak ditemukan maka langsung menuju tahap ke-6.

4. Tiap variabel pada klausa IF dari aturan tersebut yang nilainya masih kosong sekarang telah diisi. Jika semua klausa nilainya benar maka bagian THEN diminta.

5. Bagian THEN yang telah diberi nilai dari variabel tersebut disimpan dibelakang antrian variabel konklusi.

6. Jika tidak ada lagi variabel yang berisi pernyataan IF diantrian variabel konklusi, variabel tersebut dihapus.

\section{BAB V. HASIL YANG DICAPAI}

\subsection{Hasil Penelitian}

Penelitian sudah sampai pada pengembangan sistem pakar pencegahan DBD. Input dari sistem adalah karakteristik masyarakat (kepadatan penduduk dan akses trasnportasi umum) dan kondisi kesehatan masyarakat (keganasan virus dan angka bebas jentik Sistem pakar didesain untuk memberikan saran pencegahan epidemi DBD di suatu kelurahan, dengan mengacu pada hasil prediksi daerah dan waktu terjadi DBD yang merupakan hasil dari penelitian tahun sebelumnya .

Tampilan Antar Muka Sistem Pakar Pencegahan Demam Berdarah Dengue, sebagai berikut: 


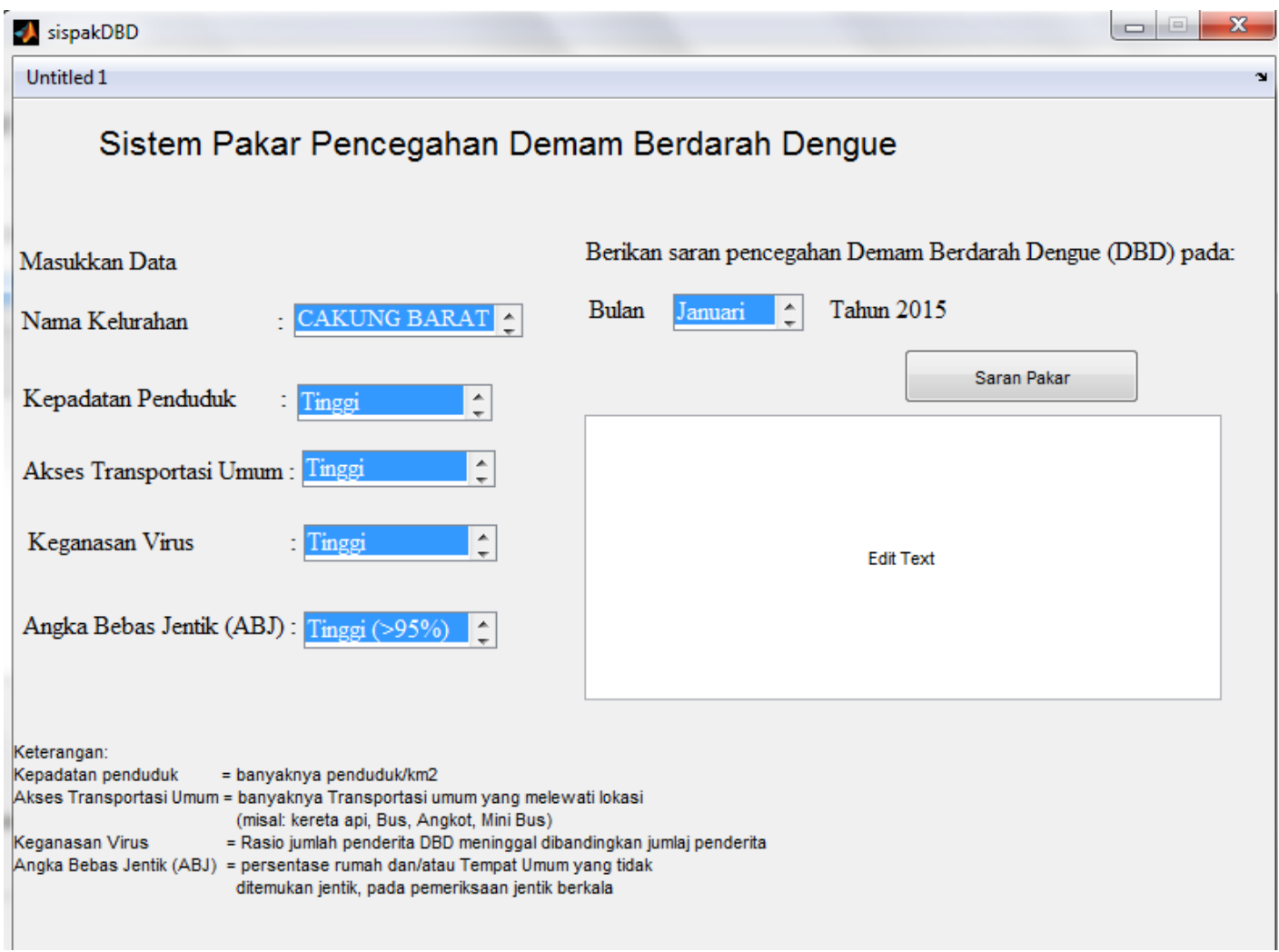

Gambar 6. Tampak Muka Sistem Pakar Pencegahan DBD

\section{KESIMPULAN DAN SARAN}

Berdasarkan yang sudah dilakukan dalam penelitian ini dapat diambil kesimpulan dan saran sebagai berikut:

\section{Kesimpulan}

1. Dengan menggunakan input karakteristik daerah (kepadatan penduduk, akses transportasi umum), kesehatan lingkungan (keganasan virus dan angka bebas jentik) telah dibuat rancangan Sistem Pakar pencegahan epidemi DBD yang memberikan saran pencegahan epidemi DBD dalam hal pengendalian vektor (nyamuk Aedes Aegepty), pengendalian jentik, penyuluhan kesehatan masyarakat.

2. Pengembangan sistem pakar pencegahan DBD berdasarkan aturan inferensi dan basis data berasal dari pendapat pakar kesehatan lingkungan, data lapangan, dan hasil penelitian.

\section{Saran}

1. Pengguna Sistem Pakar pencegahan epidemi DBD perlu dibedakan antara pengguna masyarakat umum ataupun pemerintah daerah, sehingga lebih sesuai langkah yang harus dilakukan.

2. Perlu dikembangkan sistem pakar untuk penanganan epidemi DBD dari sisi kesehatan masyarakat yang didukung pakar medis berbasis web sehingga dapat dimanfaatkan semua kalangan, setiap saat.

3. Penelitian selanjutnya, dapat dikembangkan sistem pakar yang dapat digunakan untuk meningkatkan daya tahan tubuh (auto imun) seseorang terhadap virus DBD terutama DEN-3. 


\section{DAFTAR PUSTAKA}

Alimuddin, Kudang KB, I Dewa M S, Nakao Nomura, Sumiati, Temperature Control System in Closed House for Broilers Based on ANFIS, Indonesia Journal of Electrical Engineering Vol.10.No.1 March 2012, ISSN 1693-6930 Accredited by DGHE Decree No:51/DIKTI/Kep/2010.

A.Sukmawati. 2002. Pengembangan Model Fuzzy Berlian Keunggulan Kompetitif pada Industri Pengolahan Susu Di Indonesia, Jurnal Med. Pet.Vol.25.No.2. Fakultas Peternakan IPB. Bogor.

Arafiyah $\mathrm{R}$ and Alimuddin, 2010, Prediction of price of local fruits in Jakarta with ANFIS. (Adaptive Neuro Fuzzy Inference System), International Conference AFITA Bogor Indonesia

Badan Penelitian dan Pengembangan Kesehatan DEPKES RI, 2004, Kajian Kesehatan Demam Berdarah Dengue, Jakarta

Fariza, A., Hellen, A. dan Rasyid, A. (2007). Performansi Neuro Fuzzy Untuk Peramalan Data Time Series. Seminar Nasional Aplikasi Teknologi Informasi, Yogyakarta.

Gubler, D.J. S. Nalim, R. Tan, H. Saipan, J.S. Saroso. 1979. Variation in susceptibility to oral infection with dengue viruses among geographics strain of Aedes aegypti. U.S. Naval Medical Research Unit no 2. Jakarta Detachment and National Institute of Health Research an Development. Ministry of Health. Jakarta am. J. Trop. Med Hyg, 28(6).

Hadinegoro, S.R.H., H.I. Satari. 2002. Demam Berdarah Dengue.

Hart, A. 1986. Knowledge Acquisition for Expert Systems. McGraw-Hill book Co. New York

Irnawati Marsaulina S dan Arlinda Sari Wahyu (2006) Strategi Pencegahan Kejadian Luar Biasa (KLB) Demam Berdarah melalui pendekatan faktor risiko di kota Medan,Jurnal Info Kesehatan Masyarakat Volume X No 1 2006,ISSN 1410-6434

Jang.J.S.R.,Sun. C.T.,Miztani.E., (1997), Neuro-Fuzzy and Soft Computing Prentice-Hall International, New Jersey.

Judarwanto, W. 2007. Profil Nyamuk Aedes dan Pembasmiannya. (http://www.indonesiaindonesia.com/f/13744-profil-nyamuk-aedes-pembasmiannya/)

Kristina dkk, 2004, Demam Berdarah Dengeu,
(http://www.litbang.depkes.go.id/maskes/052004/demamberdarah1.htm)

Kusumadewi, S., 2002, “Analisis dan Desain Sistem Fuzzy Menggunakan Tool Box Matlab”, Graha Ilmu, Yogyakarta.

Marimin. 2001. Teori dan Aplikasi Sistem Pakar dalam Teknologi Manajerial. Jurusan Teknologi Industri Pertanian, Fakultas Teknologi Pertanian IPB. Bogor

Pradana CP dan Kusuma Sri, 2007 Aplikasi Diagnosis Penyakit Hepatitis Untuk Mobile Devices Menggunakan J2ME, Media Informatika, Vol. 5, No. 2, Desember 2007, 8798

ISSN: 0854-4743

Poorwosoedarmo, S.S. 1988. Demam berdarah (dengue) pada anak. Universitas Indonesia. Jakarta.

Puspitasari D 2009, Sistem Pakar Diagnosa Diabetes Nefropathy dengan metode Certainty Factor Berbasis Web dan Mobile, Polteknik PNS ITS Surabaya

Soeparmanto Paiman, dkk, 2000, Peningkatan Penanggulangan Demam Berdarah Dengue (DBD) Berbasis Masyarakat dengan Pendekatan Pendidikan Kesehatan, Center for Research and Development of Health Services and Technology, NIHRD 
Suroso, T. 2001. Perubahan iklim dan kejadian penyakit yang ditularkan vektor. Semiloka Perubahan Iklim dan Kesehatan. Kerjasama Depkes-WHO, Ciloto.

Siregar, A.F. 2004. Epidemiologi dan Pemberantasan Demam Berdarah Dengue (DBD) di Indonesia. Fakultas Kesehatan Masyarakat USU. Medan.

Sintorini, M.M. 2006. Dinamika Penularan Demam Berdarah Dengue (DBD) dalam Kaitan dengan Pola Variabilitas Iklim (Studi Kasus DBD di DKI Jakarta). Jurnal Teknik Lingkungan Edisi Khusus. Universitas Trisakti. Jakarta.

Syafii, Muhammad.2006. Adaptive Neuro Fuzzy Inference System (ANFIS) untuk Diagnosa dan Tatalaksana Penyakit Demam Berdarah Dengue. Tesis Ilmu Komputer IPB, Bogor.

Sumantri Arif, 2008 Model Pencegahan Berbasis Lingkungan Terhadap Penyakit Demam Berdarah Dengue Propinsi DKI Jakarta, Disertasi Program Doktor Studi Pengelolaan Sumber Daya Alam dan Lingkungan Sekolah Pascasarjana IPB Bogor.

Taufik dan Marimin. 2001. Pengembangan system pakar fuzzy penilaian performa daya saing agroindustri. Di dalam: Prosiding Kecerdasan Komputasional II; Depok; 16-17 Oktober 2001. Depok: Universitas Indonesia. Hlm 127-133.

The Houw Liong, P.M.Siregar, R.Gernowo, F.Heru Widodo, 2007; Prediksi Jangka Panjang Iklim diIndonesia Berdasarkan Aktivitas Matahari dengan ANFIS, Seminar Masyarakat Hidrologi Indonesia, Jakarta, 